\title{
Health system reform in the United States
}

\author{
John E McDonough*
}

Abstract

In 2010, the United States adopted its first-ever comprehensive set of health system reforms in the Affordable Care Act (ACA). Implementation of the law, though politically contentious and controversial, has now reached a stage where reversal of most elements of the law is no longer feasible. The controversial portions of the law that expand affordable health insurance coverage to most U.S. citizens and legal residents do not offer any important lessons for the global community. The portions of the law seeking to improve the quality, effectiveness, and efficiency of medical care as delivered in the U.S., hold lessons for the global community as all nations struggle to gain greater value from the societal resources they invest in medical care for their peoples. Health reform is an ongoing process of planning, legislating, implementing, and evaluating system changes. The U.S. set of delivery system reforms has much for reformers around the globe to assess and consider.

Keywords: Health System Reform, United States, Affordable Care Act (ACA), ObamaCare

Copyright: @ 2014 by Kerman University of Medical Sciences

Citation: McDonough JE. Health system reform in the United States. Int J Health Policy Manag 2014; 2: 5-8.

doi: $10.15171 /$ ijhpm.2014.02
Article History:

Received: 30 November 2013

Accepted: 15 December 2013

ePublished: 18 December 2013

\section{Correspondence to:}

John E McDonough

Email: jmcdonough@hsph.harvard.edu

\section{Introduction}

Health system reform is constant and global (1). Increasingly, most societies are preparing, legislating, implementing, assessing, or planning again the health system reform as a "continuous policy improvement" cycle. Across the globe, the threefold objectives of reform are familiar: increasing access to medical services, improving the quality of care, and controlling the growth of costs. The "triple aim" of improving population health, lowering per capita costs, and improving the patient experience of care, knows no borders (2). While each national government chooses priorities based on their circumstances and needs, the problems and solutions are similar.

In the United States of America, versions of national health reform have been considered for more than 100 years with notable successes and failures, mostly the latter. Yet in 2010, President Barack Obama signed into law the Affordable Care Act $(\text { ACA })^{1}$, the most ambitious health reform program ever established in U.S. history. While many components were implemented between 2010-2013; January 1st, 2014 stands out as the point-of-no-return implementation date, and the repeal of this law is now impractical.

Why and how did the U.S. reform happen? What does the ACA do? What have been the principal implementation challenges? What is the future of reform in the U.S. and what does the ACA mean in the context of the global health reform? I will address these questions in this perspective.

Why and how did the U.S. health reform happen?

Before Barack Obama, other U.S. Presidents tried and failed to achieve the national health reform, most recently Harry Truman in the late 1940s and Bill Clinton in 1993-94, with

1. Also known as the Patient Protection and Affordable Care Act (PPACA) and, unofficially, as "ObamaCare." one exception. In 1965, President Lyndon Johnson achieved passage of a law establishing both Medicare to provide public insurance for senior citizens and Medicaid to provide public insurance for some low-income families. Through the time of Johnson's Administration, reform focused only on expanding access to health insurance. With the establishment of Medicare and Medicaid and the need to control the rising costs of these programs, all future reform efforts also sought to address the varying forms of cost control and quality improvement.

Over more than three decades, a wealth of empirical evidence demonstrated that while the U.S. spent far more than that of any other advanced society on medical services, its quality, efficiency, and public health indicators were mediocre by international standards, and we were the only advanced nation to deny financial protection to many of our citizens from the costs of serious illness $(3,4)$.

Between 2005-2008, sensing a potential new reform opportunity, significant segments of American society began speaking for comprehensive national health reform, including organizations of physicians, hospitals, insurance companies, pharmaceutical and medical device manufacturers, labor unions, business groups, philanthropic foundations, and others. In 2006, the state of Massachusetts adopted its own health reform plan to expand insurance to nearly all its residents, attracting support from both Republican and Democratic Party leaders (5). This success encouraged advocates that similar reform at the national level might overcome familiar political divisions. Key stakeholders insisted that the national reform must also address quality and costs, not just access, as Massachusetts had done. This ferment influenced the political sector. Beginning in 2007, leading candidates for the Democratic Party's presidential nomination began advancing comprehensive reform plans, notably Hillary Clinton and Barack Obama. In early 2009, 
newly inaugurated President Barack Obama began working with Democratic majorities in the U.S. Senate and House of Representatives to advance comprehensive reform legislation. In June, key committees in both chambers began advancing formal legislative drafts. As specific language replaced general principles, opposition and conflict emerged. In particular, Republican lawmakers began withdrawing from prior supportive stances to declare opposition. In the summer of 2009, a new American political movement, named the "Tea Party," composed of conservative and libertarian activists, focused on opposition to "ObamaCare" as their rallying point. By fall, nearly all Republican office holders had turned against the reform, leaving Democrats to push forward alone.

A contentious and arduous legislative process resulted in the passage and signing of the ACA by President Obama on March 23, 2010. Only Democrats supported the final passage as not a single Republican member of the Senate or House voted for the bill. The historic national health reform had been achieved, though on a shaky political foundation.

\section{What does the Affordable Care Act do?}

The ACA is the only significant federal law ever approved in the U.S. that attempts to achieve "comprehensive" health reform, meaning improvement on all three dimensions of access, quality and cost control (6). Just as a book is divided into chapters, a U.S. federal law is divided into "titles" and the ACA includes ten titles, 61 sub-titles, and 487 sections-each embodying at least one substantive public policy change. Table 1 provides a succinct outline of the ten titles to illustrate the law's scope, breadth, and ambition. In this brief summary, I will outline key reforms relating to access, quality, and costs (7).

Access. The ACA's essential purpose is to establish a new structure, so that nearly all citizens and legal residents will have access to affordable health insurance coverage. This is achieved in two ways, expanded Medicaid for most low-income Americans, and subsidized private insurance for lower- and middle-income Americans who cannot obtain coverage elsewhere.

Medicaid is a federal-state partnership, providing health coverage for many, though not all, low-income Americans. As approved in March 2010, the ACA expands coverage to nearly all low-income citizens who cannot obtain insurance elsewhere. However, a U.S. Supreme Court decision on the constitutionality of the ACA in June 2012 ruled that this expansion must be optional, not mandatory, for state governments. As of December 2012, 26 of the 50 states have elected to implement this expansion, though other states continue to consider and may join at any time.

Uninsured individuals with incomes too high to qualify for Medicaid can obtain private health insurance through new federal or state government-sponsored websites called Health Insurance Marketplaces. Those in lower or middle-income categories can obtain subsidies to lower the cost of premiums and related cost sharing. Higher-income, individuals, also can purchase coverage, though without financial assistance. For the first time, insurance companies will be prohibited from considering an applicant's medical history in the issuance, rating, or pricing of policies.

These and other changes represent the fundamental reform of U.S. health insurance, and are projected to lower the numbers of uninsured by 2019 from a projected 55 million to about 30 million; the largest segment of remaining uninsured will be individuals eligible to enroll in coverage, though not signed up. The ACA also contains a "mandate" on most individuals to purchase health insurance or to pay an annual tax penalty. Quality and Cost Control. Though often considered independently, the ACA treats improvements in the quality, efficiency, and effectiveness of medical care as primary approaches to achieve both better quality and cost control. Table 2 outlines the key reforms included in the law. Many ACA initiatives seek to move the U.S. financing system away from fee-for-service reimbursement that rewards medical providers for the volume and quantity of services, and toward a capitated or global payment model which rewards based on improvements in quality, efficiency, and outcomes of care. The ACA establishes many new organizational forms including "Patient-centered medical homes" and "accountable care organizations". Hospitals with high rates of "readmissions" of Medicare patients within 30 days after discharge as well as hospitals with high rates of hospital acquired infections are now subject to federal payment penalties. A new "Patient

Table 1. The essential structure of the ACA

\begin{tabular}{|c|c|c|}
\hline Title & Name & Purpose \\
\hline 1 & Quality Affordable Coverage & To expand private health insurance and strengthen insurance industry regulation \\
\hline II & Role of Public Programs & To expand Medicaid for lower-income adults and families \\
\hline III & Improving Quality and Efficiency in Healthcare & To improve the quality and efficiency of medical care, especially Medicare \\
\hline IV & $\begin{array}{l}\text { Prevention Chronic Disease and Improving Public } \\
\text { Health }\end{array}$ & To create new initiatives to advance health promotion and disease prevention \\
\hline V & Healthcare Workforce & To increase the numbers and improve the quality of the healthcare workforce \\
\hline VI & Transparency and Program Integrity & To combat fraud and abuse, and to promote transparency in healthcare \\
\hline VII & Innovative Medical Therapies & To permit the manufacture and sale of biopharmaceutical similar drugs (biosimilars) \\
\hline VIII & $\begin{array}{l}\text { Community Living Assistance Services and } \\
\text { Supports }\end{array}$ & $\begin{array}{l}\text { To create an insurance program to provide cash assistance to disabled persons (repealed on } \\
1 / 1 / 2013 \text { ) }\end{array}$ \\
\hline IX & Revenue Provisions & To establish new taxes and fees to pay for the programs and benefits created in the law \\
\hline $\mathrm{X}$ & Strengthening Healthcare for All Americans & Composed of amendments and new additions to titles I-IX \\
\hline
\end{tabular}


Table 2. Examples of quality and system reform innovations in the ACA

\begin{tabular}{|c|c|c|}
\hline ACA Title/ Section & Name & Purpose \\
\hline III/3022 & Accountable Care Organizations & $\begin{array}{l}\text { New vertically-integrated provider organizations to assume the risk for patient } \\
\text { outcomes and health }\end{array}$ \\
\hline II/2703 & Patient-Centered Medical Homes & Coordinated primary care for low-income and chronically ill \\
\hline III/3025 & Hospital Readmissions & Penalties on hospitals with high rates of readmissions within 30 days of discharge \\
\hline III/3008 & Hospital-Acquired Infections & Penalties on hospitals with high rates of healthcare associated infections \\
\hline VI/6301-2 & $\begin{array}{l}\text { Patient-Centered Outcomes Research } \\
\text { Institute }\end{array}$ & $\begin{array}{l}\text { New institute to commission research on comparative effectiveness of therapies and } \\
\text { treatments }\end{array}$ \\
\hline III/3002 & Physician Quality Reporting & Physicians must report quality data or face financial penalties \\
\hline $1 / 3403$ & Administrative Simplification & Reducing paperwork and administrative burdens \\
\hline VII & Biosimilar Drugs & Allowing manufacturing, marketing and sale of biopharmaceutical similar drugs \\
\hline III/3001 & Hospital Value-Based Purchasing Program & Payments to hospitals will be tied to performance on quality measures \\
\hline III/3011 & National Quality Strategy & $\begin{array}{l}\text { Coordinated and annually updated strategy on national healthcare quality } \\
\text { improvement }\end{array}$ \\
\hline IV/4001 & National Prevention Strategy & National coordinated strategy to emphasize health promotion and disease prevention \\
\hline V/5011 & National Workforce Commission & $\begin{array}{l}\text { National data collection and analysis and policy recommendations to improve the } \\
\text { quantity and quality of the workforce }\end{array}$ \\
\hline
\end{tabular}

-Centered Outcomes Research Institute" (PCORI) is launching an ambitious research agenda on the comparative effectiveness of medical treatments and therapies.

Other provisions to control costs go beyond the delivery system reforms. New controls are established to prevent fraud and abuse. New structures emphasize health promotion and disease prevention, including the creation of a National Prevention Strategy (released in June 2011) (8). Other reforms will improve the size and effectiveness of the nation's healthcare workforce. Title VII seeks to lower the growth in biopharmaceutical costs by authorizing the manufacturing, marketing and sale of the socalled "biological similar" products.

What have been the principal implementation challenges? The ACA has experienced among the most controversial and conflictual implementations of any social welfare policy law in American history. Republican and conservative forces have mobilized in every conceivable political direction to thwart implementation backed by significant financial investments from opposition stakeholders and ideological adversaries. The most significant was the legal challenge that resulted in a ruling from the U.S. Supreme Court on June 28th, 2012 (9). The court's decision, by a narrow 5-4 vote, upheld the constitutionality of the entire law and the individual mandate, though requiring that the Medicaid expansion be optional for states. Other legal challenges have failed to reach the high court, though some are still in process. The U.S. House of Representatives, controlled by a Republican majority since early 2011, has taken more than 45 votes to repeal or undermine the law-none of which passed the Democratic-controlled Senate; the House has been able to impede the flow of funding for implementation of many ACA elements.

The partnership envisioned in the ACA between the federal and state governments has been challenging, especially in states with Republican governors. Only half the states have adopted the Medicaid expansion in spite of generous federal financing, and fewer than 20 have chosen to operate their own health insurance marketplaces, opting for the federal government to establish these entities. A faulty and flawed launch of the marketplace websites in October 2013 became a serious, selfinflicted wound by the Obama Administration as millions of potential customers were unable to enroll; while problems have been corrected, reputational damage endures.

The ACA's essential implementation date has always been January 1st, 2014 when the Medicaid expansions, the private insurance subsidies, the individual mandate, and the health insurance regulatory reforms all took effect. With the launch of these reforms, complete repeal of the ACA is now improbable.

What is the future of U.S. health reform and what does the ACA mean for global reform?

In the U.S., the passage of any significant law is the end of a lengthy legislative process, and the initiation of an ongoing implementation and improvement process as the nation comes to understand the law's advantages, disadvantages, flaws, and errors. The prior major federal health law that established Medicare and Medicaid in 1965 has been subject to continuous debate, review and amendment for nearly 50 years. So it will be with the ACA as the nation's public and healthcare stakeholders evaluate its successes and failure, and as lawmakers modify the law to meet the changing needs of a dynamic society.

The ACA's access and insurance coverage reforms represent an effort by the U.S. to catch up with the health financial security already guaranteed to residents of all other OECD nations, as well as by a growing number of less advanced nations including Mexico, Thailand, and Turkey. While these reforms are of immense consequences to the U.S. public, they offer no lessons for other nations, all of which cover their citizens with far less 
overhead, administrative bureaucracy, or complexity.

The ACA's efforts to improve the efficiency, effectiveness, and quality of medical care demand attention, and will be watched and evaluated by health system reformers around the globe for years to come. The ideas and concepts, embedded in the ACA's health system reforms, represent the cutting edge thinking about health system transformation and continuous improvement.

The U.S. health system is one of the world's leading innovation labs in reforming medical care delivery, partially because our society is so open to recognizing our health system's faults and deficiencies. The U.S. health system underperforms other societies in "top-down" governance and managementlacking a "controlling legal authority" in our federalized and Balkanized system. Alternately, the U.S. system outperforms many other societies in "bottom-up" innovation and localized responsibility. Our hospitals floors, research labs, insurance agencies, technology innovators, philanthropies, and others, are hotbeds of ideas and experimentation. So many ideas, so much knowledge about what "works" comes from the U.S. system. For far too long, the U.S. public's interest in health policy has stopped at the nation's borders, characterized by a narrow and self-defeating mindset that we have nothing to learn from other nations' systems. That, too, is changing, as evidenced by the Commonwealth Fund's International Health Policy Center (10). I hope the exchanges and cross learning will grow more robustly in the years ahead.

Ethical issues

Not applicable.
Competing interests

The author declares that he has no competing interests.

Author's contribution

JEM is the single author of the manuscript.

\section{References}

1. Frenk J. The global health system: strengthening national health systems as the next step for global progress. PLoS Med 2010; 7: e1000089.

2. Dentzer S. The Triple Aim Goes Global. Health Aff (Millwood) 2013; 32: 638

3. Institute of Medicine. Crossing the Quality Chasm [internet]. 2001. Available from: http://www.iom.edu/Reports/2001/Crossing-theQuality-Chasm-A-New-Health-System-for-the-21st-Century.aspx.

4. Institute of Medicine. Coverage Matters: Insurance and Health Care. Washington, DC: National Academies Press; 2001.

5. McDonough J, Rosman B, Phelps F, Shannon M. The Third Wave of Massachusetts Health Care Access Reform. Health Aff (Millwood) 2006; 25: W42-431.

6. Affordable Care Act [internet]. Available from: http://www.hhs.gov/ healthcare/rights/law/

7. McDonough J. Inside National Health Reform. Berkely, California: University of California Press and the Milbank Fund; 2011.

8. U.S. Surgeon General. National Prevention Strategy [internet]. Available from: http://www.surgeongeneral.gov/initiatives/prevention/ strategy/

9. McDonough J. The Road Ahead for the Affordable Care Act. $N$ Engl J Med 2012; 367: 199-201.

10. Commonwealth Fund. International Health Policy Center [internet]. Available from: http://www.commonwealthfund.org/Topics/InternationalHealth-Policy.aspx 